\title{
Surface Immunoglobulin
}

National Cancer Institute

\section{Source}

National Cancer Institute. Surface Immunoglobulin. NCI Thesaurus. Code C573.

Immunog lobulin containing a transmembrane region and expressed on the plasma

membrane of a B cell. Contrast with secreted Ig which has no transmembrane region but which can still be bound to the cell surface via Fc receptors. 